\title{
Property as Platform: Coordinating Standards for Technological Innovation
}

\author{
Henry E. Smith
}

January 23, 2013

\begin{abstract}
This paper will examine the coordination of inputs to the development and use of technology as a problem in the theory of property. Recent misunderstanding of property, in terms of both the substance of its rights and the implications of its remedies, have presented property as an obstacle to - rather than as a platform for - rapidly evolving technology. An information-cost theory of property stresses modularity and standardization, hybrid systems of private and common rights, and the traditional safety valve of equity, all of which suggest solutions to problems not only of appropriation, but of coordination and opportunism surrounding intellectual property and technology standards.
\end{abstract}

\section{Introduction}

Property is easy to miss. Economists and lawyers tend to focus on the most difficult and yet definable problems, which when considered one by one, appear to call for special contractual or regulatory solutions. And such problems do exist. But they take place against a backdrop of complex social interactions governed by the law of property. Most of the time, property serves as a platform for a mass of interactions. We do not - nor could we - live in a world of freely interacting transactions or contracts; instead these interactions are organized, prioritized, and packaged by property law. Property's function as a platform is hard to notice, or when it is salient, it appears to form an obstacle to efficiency, as when exclusion rights prevent use by multiple parties of nonrival or uncrowded resources.

Standard setting in technological industries exemplifies the obvious pitfalls and hidden promise of property law. Property, here in the form of intellectual property, appears to threaten the ability of SSOs to choose standards without being unfairly and inefficiently surprised by the market power exercised by someone with a patent right that covers the standard. ${ }^{1}$ What's worse, the adoption of a technical standard might amplify the patentee's market power. But property is not simply about exclusion. Rather exclusion is the starting point for a more complex and pervasive role that property plays in private law - property as platform. Property

${ }^{1}$ See e.g., Fed. Trade Comm'n, The Evolving IP Marketplace: Aligning Patent Notice and Remedies with 
law employs a variety of devices, from boundary placement, to governance rules, to traditional equity, in order to constrain strategic behavior.

To serve a platform for private interactions, the law of property employs modules and interfaces. By setting boundaries around clumps of interactions (modules) and defining the permitted interface between them, the system can manage the complexity of private interactions. ${ }^{2}$ Because interactions take place in one or a few modules and not the system as a whole, modularization permits specialization. ${ }^{3}$ For example, an owner can specialize in developing and exploiting information about the asset she owns. Remote parties need not know anything about the owner or her plans; the law of trespass and theft merely direct her to steer clear in a fashion that is simple and easy to comply with. "Information hiding" thus occurs within the package of property rights over parcels of land or objects like a parked car. And, as we will see, this use of modular components that hide information extends to more complex forms of property as well. Modularization can take many forms, and it lies at the heart of property law's contribution to organizations. Asset definition and the separation of control from use lead to "entity property," 4 which allows for specialization of management and various monitoring functions. Corporations, trusts and even landlord tenant involve different actors controlling assets and benefiting from them. A specialist can do the controlling in each of these types of situation.

This article will first present a framework for property that captures its role in organizations, intellectual property, as well as property law itself. Separation in property allows for specialization but also gives rise to the potential for strategic behavior. Each specialist may only maximize locally, which can lead to social losses. To counteract this strategic behavior, a combination of boundary placement and interface rules can be used, up to the point where they are more costly than the losses from strategic behavior. Because of the benefits and cost of separation, property, IP, and organizations all exhibit an exclusion-governance architecture, ${ }^{5}$ with targeted rules at interfaces to constrain strategic behavior. The article then applies this framework to SSOs and shows that separation of the standardization function is yet another type of property separation and specialization. As with other dimensions of separation, strategic behavior becomes possible. But contrary to

\footnotetext{
${ }^{2}$ Henry E. Smith, Property as the Law of Things, 125 HARV. L. REv. 1691 (2012).

31 Carliss Y. BaldWin \& Kim B. Clark, Design Rules: The Power of Modularity (2000); MANAGing IN THE Modular AGE (Raghu Garud et al. eds., 2003); Richard N. Langlois, Modularity in Technology and Organization, 49 J. Econ. BEHAV. \& ORG. 19 (2002); Ron Sanchez \& Joseph T. Mahoney, Modularity, Flexibility, and Knowledge Management in Product and Organization Design, 17 Strategic MgmT. J. (SPECial IsSue) 63 (1996).

${ }^{4}$ Thomas W. Merrill \& Henry E. Smith, Property: Principles And Policies 646-806 (2d ed. 2012).

${ }^{5}$ Henry E. Smith, Exclusion Versus Governance: Two Strategies for Delineating Property Rights, $31 \mathrm{~J}$. LEGAL STUD. S453 (2002).
} 
some widespread views, the tools of property do not simply cause the problem of opportunistic hold up in SSOs; property also provides some solutions, in this case through doctrines of equity that are aimed at counteracting opportunism in general.

\section{Modularization and Separation}

A good place to start in thinking about property is in considering what it is not. In a zero transaction cost world, all interactions between people could be taken care of by contract. ${ }^{6}$ The scope and nature of property rights would be beside the point. ${ }^{7}$ We could, for example define entitlements in the narrowest fashion and as availing between pairs of members of society. In the hypothetical world, every (hypothetical) contract in principle could interact with (for example, its terms depend on) any other - A will sell X to B only if C sells $Y$ to D etc., etc. This would be impossibly complex and costly, and not just because not all of these interactions do not happen. The potential interactions also mean that actors will have to trace out the implications in the entire system, which because of this complexity will be difficult and hard to predict. ${ }^{8}$ But because most of these potential interactions are just that - potential and almost certainly not actual or important - they can be cabined, channeled, or even ruled out without much reduction in the ability of the system of transactions to serve its purpose. So one thing property does is to form a shortcut over this full or complete set of entitlements. A starting point is to define things within which interactions are important and actual (complementary attributes) and set boundaries around them where the interactions are relative sparse (but not zero). That is, the basic "things" of property emerge from what Simon called a "nearly decomposable system." 9 A complex system is nearly decomposable when it can be broken into components - modules - within which interactions can be intense but invisible from the outside; interfaces between modules then take care of the remaining relatively sparse interactions. Complexity can be managed in this way, in that what happens in a module will impact the rest of the system in stylized ways - through the interface - and information costs will thus not spiral out of control. Crucially one module can be substituted for another as long as the interface conditions are met. ${ }^{10}$ In this way, interface conditions are a set of standards - the standards for the interoperation of the modules.

\footnotetext{
${ }^{6}$ R.H. Coase, The Problem of Social Cost, 3 J.L. \& Econ. 1, 7 (1960).

7 Brian Angelo Lee \& Henry E. Smith, The Nature of Coasean Property, 59 InT'L REV. ECON. 145 (2012); Henry E. Smith \& Thomas W. Merrill, Making Coasean Property More Coasean, 54 J.L. \& Econ. S77 (2011).

8 Herbert A. Simon, The Sciences of the Artificial 210 (2d ed. 1981); see also Sanjeev Arora \& BoAz Barak, Computational Complexity: A Modern ApProach (2009).

${ }^{9}$ Simon, supra note 8 , at 209-11.

10 BALDWIN \& CLARK, supra note 3, at 12-13, 123-46.
} 
Property law itself sets these standards. Property has an in rem aspect: it defines rights that avail against others generally. This itself is a big shortcut over a collection of in personam rights between the owner and each other person. ${ }^{11}$ For reasons of information cost, the in rem aspects of property are the most standardized: property needs to be simple when its audience is a large and impersonal group of people who may be socially distant. ${ }^{12}$ Thus, trespass and theft law are simple, whereas nuisance law is more complex, and those areas of property law that shade off into contracts, as in landlord tenant law, bailments and trust law are allowed to be more detailed still. ${ }^{13}$ Most explicitly (especially in the civil law), the numerus clausus principle keeps the number of basic property forms to a short standardized menu. ${ }^{14}$ This helps people measure property rights because they know what to look for and helps violators steer clear of violations. Property rights are also more transferable when the dimensions along which they can vary are limited or at least well defined. ${ }^{15}$

Much of what property does, in terms of setting up things and defining rights over them, involves fragmentation and separation. To take the numerus clausus again, the variety of rights on the menu can be thought of as ways that the fee simple or full ownership can be broken into pieces. Thus, a life estate and reversion (or remainder) is possible, as is a lease and a reversion, but not a lease for life and reversion. ${ }^{16}$

Fragmenting property is necessary in order to make specialization possible. On Robinson Crusoe's Island, at least when he was alone, there was no need for

${ }^{11}$ Hohfeld famously attempted to reformulate in rem rights as a collection of in personam rights. Wesley Newcomb Hohfeld, Fundamental Legal Conceptions as Applied in Judicial Reasoning, 26 YALE L.J. 710, 718-33 (1917). See also Thomas W. Merrill \& Henry E. Smith, The Property/Contract Interface, 101 Colum. L. Rev. 773, 780-89 (2001); Albert Kocourek, Rights in Rem, 68 U. PA. L. REv. 322,335 (1920).

12 Henry E. Smith, The Language of Property: Form, Context, and Audience, 55 STAN. L. Rev. 1105, 1148-57 (2003); Merrill \& Smith, supra note 11.

${ }^{13} I d$.

${ }^{14}$ Thomas W. Merrill \& Henry E. Smith, Optimal Standardization in the Law of Property: The Numerus Clausus Principle, 110 YALE L.J. 1 (2000).

15 Id.; Henry E. Smith, Standardization in Property Law, in RESEARCH HANDBOoK ON THE EConomics of Property LAW 148 (Kenneth Ayotte \& Henry E. Smith eds., 2011). Hansmann and Kraakman wrongly assume that title records necessarily render any standardization irrelevant. Henry Hansmann \& Reinier Kraakman, Property, Contract, and Verification: The Numerus Clausus Problem and the Divisibility of Rights, 31 J. LEGAL STUD. S373, S416-17 (2002).

16 Merrill \& Smith, supra note 14. 
property, no specialization, and no externalities. One owner and one gigantic fee simple make for an uninteresting system. As soon as property is divided in any way, the potential for externalities and the need arises to control them with interface conditions. ${ }^{17}$ In the life estate example, the law of waste governs the relations between the present interest holder and the holder of a future interest. ${ }^{18}$

Property law provides for more types of fragmentation than this. Indeed, separation is the key to entity property, in which rights are divided along dimensions that allow for specialization in roles involving control and enjoyment of assets. This separation is a function of property, in part because it cannot be achieved by contract alone. Consider some of the dimensions along which separation and modularization occur. In each case separation allows for specialization but also strategic behavior, and it is the latter that helps explain the complexity of the law at the interface between modules.

1. Separation of assets. Property law exhibits a range of strategies. A starting point is to define a thing over which rights are protected through an exclusion strategy. ${ }^{19}$ Important and detachable problems can be addressed through governance strategies - by contract, nuisance, zoning, other off-the-rack law, or custom. The result is a modular architecture. The exclusion strategy implemented by trespass, theft law, and the like allows the owner or owners to take actions with little interference, and outsiders need not know much about the internal activities (or sometimes inactivity) constituting use. Problems arise where interactions are intersected by the module boundary. Externalities then may need to be internalized, as where the law of nuisance governs which odors can be left to waft away over the neighborhood. Owners can also contract in order to achieve ends that the exclusion strategy does not enable on its own.

One class of problems that stem from asset definition comes under the heading of strategic behavior. Owners may engage in activities contrary to the purpose of the right. They may engage in what Dan Kelly labels "strategic spillovers" - activities undertaken for purposes of being paid to stop..$^{20}$ Opening a stable in order to coerce payment from the neighbors in return for shutting down is a classic example.

\footnotetext{
${ }^{17}$ Setting boundaries correctly minimizes externalities, which allows what would otherwise be an externality to be hidden, Richard N. Langlois, The Secret Life of Mundane Transaction Costs, 27 ORGANIZATION STUD. 1389, 1397 (2006), or the interface can be enriched to account for the interaction (as in nuisance, easements, and covenants). These methods correspond roughly to exclusion and governance strategies. See Smith, supra note 5.

181 American LaW of Property § 3.78 (A. James Casner, ed. 1952); Powell on Real Property § 56.05.

${ }^{19}$ Smith, supra note 5; Smith, supra note 2.

20 Daniel B. Kelly, Strategic Spillovers, 11 CoLum L Rev. 1641 (2011).
} 
Strategic behavior can also occur across the boundaries of different types of property regimes. On a macro scale, the tragedy of the commons is an example of arbitrage between common (or rather open access) and private property. The incentive for overuse only arises because units taken from the commons are private. If a pond of fish were common along with fish taken form it, there would be no incentive for overuse (and perhaps one of underuse). ${ }^{21}$ If the fish in the pond and outside it were both private, there would likewise not be an incentive for overfishing, but depending on the size and nature of the resource, opportunities for specialization and risk sharing might have to be foregone. Or the agency costs of hiring fishers might have to be incurred.

One class of strategic behavior occurs where two property regimes cover the same asset. Sometimes, use on multiple scales - a form of specialization - becomes important enough to allow for overlapping modules in which some attribute is subject to multiple property modules. A semicommons exists where private and common property regimes overlap physically and the two regimes interact: a semicommons must tolerate or address the strategic behavior made possible by the enhanced access from the overlap. ${ }^{22}$ In the medieval and early modern open fields, strategic behavior of favoring one's own parcel with manure and harming others' parcels with excessive trampling of sheep was only possible though the access afforded by throwing the entire set of privately owned strips open as a grazing common during fallow periods and right after harvest. ${ }^{23}$ I have argued that enforcing a pattern of scattered narrow strips made the picking and choosing necessary to engage in this type of strategic behavior prohibitively costly, and thereby served as a governance mechanism. ${ }^{24}$ This semicommons type of overlap is particularly likely in intellectual property, because access to information is more difficult to prevent and preventing access is presumptively undesirable on account of information's nonrival character. ${ }^{25}$ Doctrines like fair use in copyright can be

\footnotetext{
${ }^{21}$ See Michael Heller, The Tragedy of the Anticommons: Property in the Transition from Marx to Markets, 111 HARv. L. REv. 621, 675 n.246 (1998) (discussing points made by William Miller about how tragedy depends on ability to convert common property into private property which can be sold).

22 Henry E. Smith, Semicommon Property Rights and Scattering in the Open Fields, 29 J. LeGAL Stud. 131, 131-32, 138-42 (2000).

${ }^{23}$ Id. at $134-38,144-54$.

${ }^{24}$ Id. at $144-54$.

25 See, e.g., Brett M. Frischmann, Evaluating the Demsetzian Trend in Copyright Law, 3 REv. L. \& ECoN. 649, 651 (2007); Robert A. Heverly, The Information Semicommons, 18 BERKELEY TECH. L.J. 1127 (2003); Lydia Pallas Loren, Building a Reliable Semicommons of Creative Works: Enforcement of Creative Commons Licenses and Limited Abandonment of Copyright, 14 GEO. MASON L. REV. 271 (2007); Peter K. Yu, Intellectual Property and the Information Ecosystem, 2005 Mich. ST. L. REV. 1, 11-12; see also, e.g., Ellen P. Goodman, Spectrum Rights in the Telecosm to Come, 41 SAN DIEGo L. REv. 269, 379403 (2004); Henry E. Smith, Governing the Tele-Semicommons, 22 YALE J. on REG. 289 (2005). Like
} 
regarded as an overlap between private rights and the public domain, and as a very complicated interface between the two.

As we will see, the various type of separation are hard to separate themselves, because they work in tandem. In common property an asset - the common pool resource - is defined, over which the common pool property regime holds sway. In some of the more elaborate common pool regimes we find that the group's collective action mechanism is elaborate enough to involve separation itself with an accompanying degree of specialization. ${ }^{26}$ In such cases, a common property regimes shades off into entity property.

2. Fragmentation across time. Perhaps the most familiar type of separation in property occurs along the dimension of time. One reason for the salience of divisions by time are their association with the system of estates in land and future interests, including their peculiar feudal-sounding terminology and technicalities. ${ }^{27}$ Thus, the life estate can be followed by a future interest in the grantor (reversion) or a third party (remainder. Various defeasible fees are interests like full ownership that end upon the occurrence of a defined event, and these present interests are followed by an array of future interests in grantors and third parties. Perhaps more important are divisions across time that occur in trusts. As we will see, the trust is very flexible and allows for a range of types of separation. Much of the division by time in trusts employs the same vocabulary of legal estates but with greater flexibility. Also more important than legal estates (as opposed to the more prevalent equitable estates, in trust) are leasehold interests. The tenant has a present possessory interest, and the landlord retains the reversion, the right to a stream of rents under the lease, and a package of nonpossessory rights and duties as defined by the lease and off-the-rack landlord tenant law.

When it comes to all these divisions by time, the major issue they throw up is the problem of strategic behavior. Given the control exercised by the present possessory interest holder, the strategic behavior is mostly a problem of misuse of that control. The law's major contribution is the law of waste, which seeks to cabin the behavior of a present interest holder when it diverges too far from overall wealth maximization. ${ }^{28}$ Likewise, we fear the behavior of the trustee in a trust (see below), and fiduciary duties are designed to constrain the real dangers of strategic

tangible property rights, IP rights are not absolute. Michael A. Carrier, Cabining Intellectual Property through a Property Paradigm, 54 DuKE L.J. 1 (2004).

26 Elinor OSTRom, Governing the COMmons: THE EVOLUTION OF INSTITUTIONS FOR COLLECTIVE ACTION (1990); see also GARY D. LIBECAP, CONTRACTING FOR PROPERTY RIGHTS (1989)]

${ }^{27}$ LEWIS M. Simes \& AlLAN F. SMith, The LAW OF Future InTERESTS (2d ed. 1956).

28 The law uses a combination of rules of thumb and contractarianism is police this behavior. Asking courts to implement a wealth maximization standard directly probably exceeds their capacities.

(Pace Posner.) 
behavior. ${ }^{29}$ In landlord-tenant law, the split of interests is not a clean present-future one, and the potential for strategic behavior on the part of both the tenant and the landlord are a major concern reflected in the law of landlord-tenant. In addition to the waste doctrine, the various rights and remedies, such as abandonment and surrender, the duty to mitigate and the like, set the framework for the strategic interaction of the current tenant and the landlord.

3. Separation of Control Rights and Entity Property. Many if not all of these special features of firms have something in common: the modularity afforded by their property aspect. Indeed, organizations can be thought of as "entity" property. ${ }^{30}$ Organizations are modular in that interactions may be intense within the organization but this information is largely hidden to those outside. Interface conditions specify what information is relevant to the outside. Consider some of the special aspects of business organizations that are difficult to capture by private contracting.

Specialization can be served by several forms of separation. Most familiar is the separation of ownership and control. ${ }^{31}$ Indeed, forms of what Merrill and I call "entity property" separate control from other dimensions of ownership in order to promote specialization. Two types of beneficial use can be separated from control: possessory and non-possessory. Examples of some form of control being separated from possessory benefits come from common interest communities and landlord tenant. In the latter, the landlord wields much decision-making power, and the tenant has possession and a related package of rights. This allows the landlord to specialize in managing the property and bearing certain kinds of long-term risk. In common interest communities, owners of individual units have more local control and exercise collective control over common areas and amenities.

In entity property with separation of control from non-possessory beneficial use, the party with control also has possession, leaving a stream of value for the beneficiary. This is clear in the case of a trust, in which the trustee has legal title and usually possession, whereas the beneficiary is entitled to the stream of value, managed in accordance with the standard fiduciary duties of trustees. ${ }^{32}$

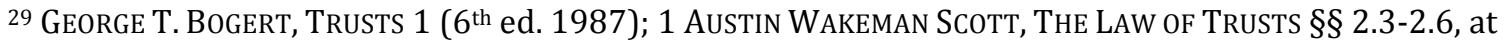
40-48 (1939); RESTATEMENT (SECOND) OF TRUSTS § 2 (1959) (trust is "a fiduciary relationship with respect to property, subjecting the person by whom the title to the property is held to equitable duties to deal with the property for the benefit of another person, which arises as a result of a manifestation of an intention to create it"); see also Melanie B. Leslie, Trusting Trustees: Fiduciary Duties and the Limits of Default Rules, 94 GEo. L.J. 67 (2005); Paul B. Miller, Justifying Fiduciary Remedies (University of Toronto Law Journal, forthcoming), available at SSRN: http://ssrn.com/abstract=2167883.

${ }^{30}$ MeRRILL \& SMITH, supra note 4, at 680-81.

31 Adolf A. Berle \& Gardiner C. Means, The Modern Corporation and Private Property (1933).

${ }^{32}$ For various discussion of trusts as entity property, see Merrill \& Smith, supra note 4, at 778-803;
} 
Interestingly, the literature on business organizations, which has long been dominated by the theory of the corporation as a nexus of contracts, ${ }^{33}$ is now beginning to emphasize more property-like aspects of organizations. ${ }^{34}$ And it is precisely the ability to compartmentalize and hide information that is property's contribution to organizations. Daniel Spulber even defines a firm as one in which the decision making about the firm's objectives can be separated from the personal preferences of its residual owners. ${ }^{35}$ This is related to the separation of ownership and control and is effected by devices that can be termed "entity property."

Indeed, the separation of ownership and control is the most famous version of entity property. When Berle and Means noticed what we would now call the agency problem, they conceived it as a problem for property. ${ }^{36}$ They believed that separating ownership from control meant that corporations called into question the validity of private property in the first place. On the contrary, the separation of ownership and control can be regarded as an important type of separation with the benefits and challenges of other types of property modularization.

Specialization through more fine-grained modularization takes place against the backdrop of a nearly decomposable system. Each of the kinds of separation discussed above carries with it problems of strategic behavior and externalities. Asset partitioning can lead to divergence of incentives: think of the preference for risk of residual claimants versus holders of a debt-like claim. The agency costs of the separation of ownership and control are also very familiar.

4. Liability and Asset Partitioning. Various business organizations define pools of assets and determine the access or lack of access of classes of creditors to those pools. Hansmann and Kraakman have called this "asset partitioning." 37 Familiar

Henry Hansmann \& Reinier Kraakman, The Essential Role of Organizational Law, 110 YALE L.J. 387, 405, 416-17 (2000); Robert H. Sitkoff, Trust Law as Fiduciary Governance Plus Asset Partitioning (Harvard University Law \& Economics Discussion Paper No. 711, Nov. 21, 2011, forthcoming in L. Smith, ed., The Worlds of the Trust), available at SSRN: http://ssrn.com/abstract=1962856.

33 See, e.g., Frank H. EASterbrook \& Daniel R. Fischel, The EConomic Structure of Corporate LaW 17173 (1991); Michael C. Jensen \& William H. Meckling, Theory of the Firm: Managerial Behavior, Agency Costs and Ownership Structure, 3 J. Fin. Econ. 305, 311 (1976).

${ }^{34}$ See, e.g., John Armour \& Michael J. Whincop, The Proprietary Foundations of Corporate Law, 27 OXFORD J. LEGAL STUD. 429 (2007); Hansmann \& Kraakman, supra note 32, at 393-94.

35 Daniel F. Spulber, The Theory of the Firm: Microeconomics With Endogenous Entrepreneurs, Firms, MARKETS, AND ORGANIZATIONS (2009); Daniel F. Spulber, Discovering the Role of the Firm: The Separation Criterion and Corporate Law, 6 BERKELEY BuS. L.J. 298 (2009).

36 BERLE \& MEANS, supra note 31; Jensen \& Meckling, supra note 33.

37 Hansmann \& Kraakman, supra note 32, at 393-94. 
limited liability (for example, for corporate shareholders) is a form of what they call "defensive asset partitioning": the firm's creditors cannot come after the non-firm assets of the firm's owners. By contrast, affirmative asset partitioning protects the firm's assets from the owner's creditors: this important feature is often taken for granted, but it would be virtually impossible to replicate this solely through contract law. ${ }^{38}$ The transaction costs of entering into and enforcing all the negative covenants would be prohibitive. This makes affirmative asset partition both property-like and an essential contribution to organization law that goes beyond contract. ${ }^{39}$ (Recall that above we noted how property itself is a shortcut over a large number of contracts.)

Consider an example of Firm A, which makes computer hardware and Firm B, a grocery chain, as illustrated in Figure 1. The boundaries around Firm A and Firm B create a modular structure. Firm A has several interfaces: it is owned by Owner 1 and Owner 2, and it has one creditor. In addition, it interacts with other actors, contractual partners, tort victims, etc. Because of defensive asset partitioning, neither the creditor nor these other actors can reach Owner 1 and his assets - only his creditor can. Affirmative asset partitioning means that Owner 1's creditor cannot reach the firm's assets - or those of the other actors, for that matter. Nor can the creditors of Firm B, the grocery chain, reach the assets of Firm A, either directly or indirectly through Owner 1. Owner 2, who owns a share of Firm A but not Firm $B$, need not worry at all about the risks and activities of Firm B. Owners (like Owner 2) and Firm A's creditor can specialize in monitoring a computer hardware business and need not know anything about groceries. More generally, what goes on in Firm $A$ is not relevant for Firm B and vice versa. As we will see, not only are they separate from the point of view of creditor-debtor relations, but all sorts of other decisions and requirements that apply to the one Firm will have no bearing on the other Firm and the actors whose interface is with it - unlike the case where the assets of the two firms were in one large firm.

38 Id. at 398.

${ }^{39} I d$. 


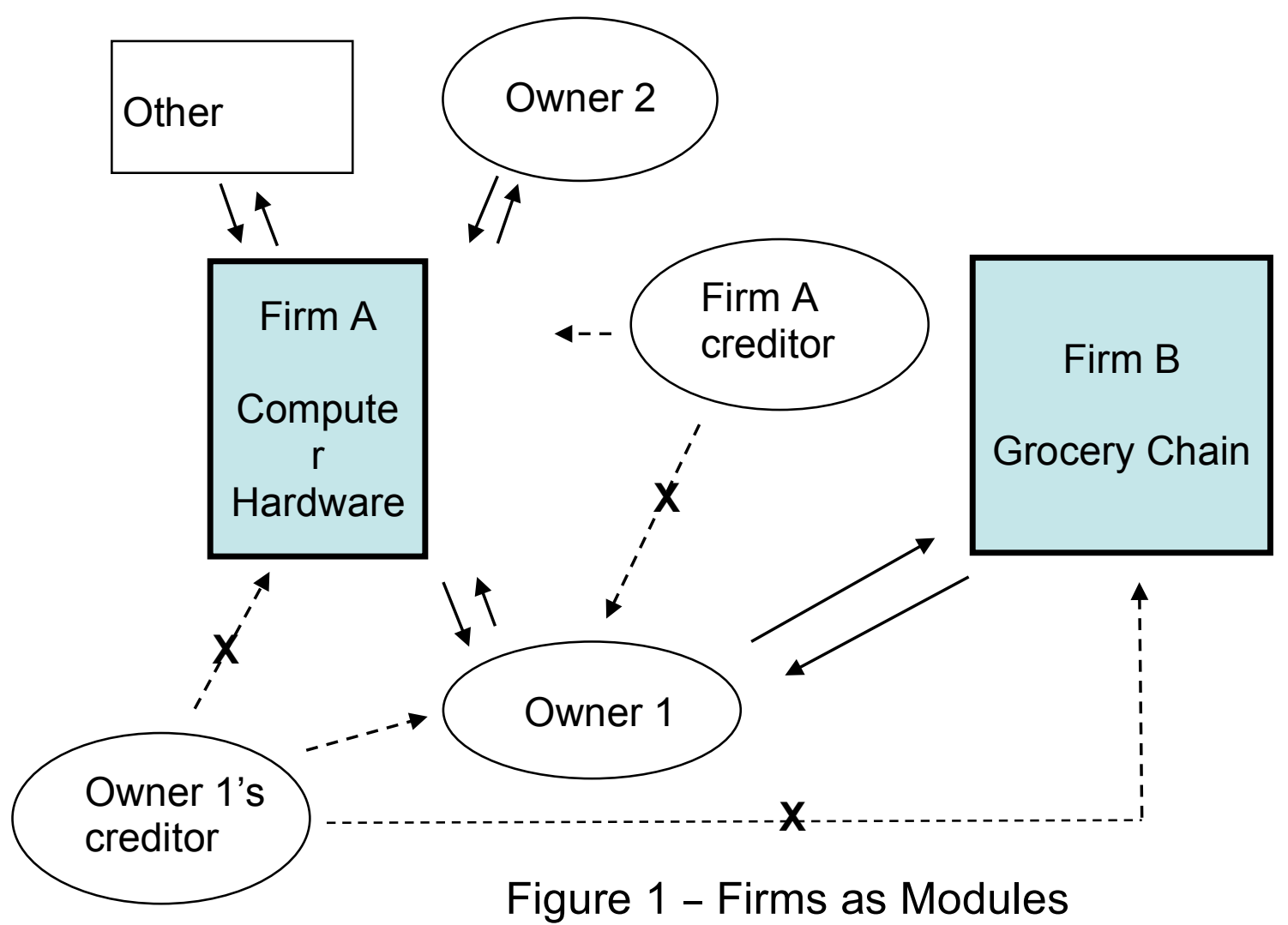

In sum, asset partitioning, like property, is also modular. Asset partitioning means that information about the firm owner's credit situation is irrelevant to the creditors of the firm, and information about the firm's creditors is of limited relevance to the firm owner's creditors. Information is blocked across modules, and this allows economization on information and the substitution of structures without massive ripple effects.

5. Ownership. In property theory, ownership has been very hard to define. The word "owner" is sometimes reserved for one with an encompassing or master interest (to which other interests revert when the expire), and yet others call the holder of any property interest an owner. ${ }^{40}$ Recently a number of property theorists have ascribed great significance to the notion of ownership as an "office." ${ }^{11}$ While

\footnotetext{
40 See, e.g., A.M. Honoré, Ownership, in OXFORD ESSAYS IN JURISPRUDENCE 107, 112-28 (A.G. Guest ed., 1961) (analyzing ownership in a "mature legal system" into eleven elements).

${ }^{41}$ See, e.g., Larissa Katz, Governing Through Owners: How and Why Formal Private Property Rights Enhance State Power, 160 U. PA. L. REv. 2029 (2012); Christopher Essert, The Office of Ownership (August 28, 2012, forthcoming, University of Toronto Law Journal), available at SSRN: http://ssrn.com/abstract=2137777; see also H.L.A. HART, ESSAYS ON BENTHAM: STUDIES IN JURISPRUDENCE AND POLITICAL THEORY 208 (1982) (seeing in the work of Jeremy Bentham a notion of the "'office' of owner of the property").
} 
not endorsing the full-blown version of these theories, I will argue that they do point to important dimensions of separation and modularization in property.

One reason ownership is important is that it allows the owner to be the locus for decision making in a kind of exclusivity. Another significant feature of ownership is the ability of a successor to step into the shoes of a prior owner. This succession is important when considering whether a restrictive covenant should bind successor owners, or for that matter, how transfer of property from one owner to another happens in the first place.

What is important here is that there be some defined package that can be wielded and transferred, without a great deal of personal information. ${ }^{42}$ To take transfer, if personal information about prior owners is relevant to a property right in transferee's hands, that will make the transfer harder to effect, because the transferee will have to measure the property rights or take greater risk of downside surprise. For purposes of transfer, it is important that property be treated as a thing that is largely depersonalized. ${ }^{43}$ An extreme example is negotiability, in which a holder in due course can take an instrument, like a check, free of defenses that would avail against the predecessor. ${ }^{44}$ In general, transferability of property rights requires the creation of legal commodities, ${ }^{45}$ which in turn requires standardization and depersonalization.

6. The Residual Claim. A particularly important module in entity property is the residual claim. Separation of decisions from the residual claim are important for specialization but give rise to agency costs.

Firms are like property in their modularity partly because they rely on the notion of residual claimancy. In the "nexus of contracts" that is the firm, these contracts are not all specified contract by contract but rather make reference to firm boundaries. In particular the delineation of the residual claim can be economized on because it relies on the "outer boundary" of the firm and its value. The residual is everything owned by the firm after all lesser interests (separately delineated) have been paid off). ${ }^{46}$

\footnotetext{
42 Smith, supra note 2.

${ }^{43}$ See Henry E. Smith, Emergent Property (forthcoming in James Penner \& Henry E. Smith, eds., Philosophical Foundations of Property Law, Oxford University Press).

${ }^{44}$ For the definition in the Uniform Commercial Code, see U.C.C. § 3-104(a) (2005).

45 BENITO ARRuÑadA, InSTITUTIONAL FOUNDATIONS OF IMPERSONAL EXCHANGE: THEORY AND POLICY OF CONTRACTUAL REGISTRIES (2012).

46 Armen A. Alchian \& Harold Demsetz, Production, Information Costs, and Economic Organization, 62 Am. Econ. Rev. 777, 781-83 (1972); Yoram Barzel, The Entrepreneur's Reward for Self-Policing, 25 ECON. INQUIRY 103 (1987); see also Oliver Hart, An Economist's Perspective on the Theory of the Firm, in ORGANIZATION THEORY 154, 160 (Oliver E. Williamson ed., 1995).
} 
Interestingly, various theories see the residual claim as a method of lowering information costs. For example, Yoram Barzel theorizes that entrepreneurs receive the residual claim because their contribution is the hardest to measure. ${ }^{47}$ By first measuring by contract the contribution of other inputs, the residual claim need only be defined as the outer boundary of the collection of assets minus these claims. Likewise, capital contributions are difficult to measure, and if one used detailed proxies to measure the contribution of capital, it would be subject to appropriation in hard-to-detect ways. ${ }^{48}$ These factors likewise are rationales for locating the residual claim with the contribution of capital.

Further, a residual claimant has incentives to monitor. ${ }^{49}$ Recently a debate has arisen over whether managers should maximize shareholder value (subject to contractual duties to other actors) or should owe duties to other stakeholders as well. ${ }^{50}$ One argument is that duties to multiple, heterogeneous stakeholders gives managers too many masters, and a duty to all of them is too difficult to evaluate, thereby weakening the set of duties overall. ${ }^{51}$ Ultimately this is an empirical question, involving too the ability of other constituencies to protect themselves through contract, but the specialization of monitoring by the residual claimant partakes of the advantages of modularity.

7. Standardization. If entity property is the result of modularization, then it is worth considering other types of separation. One function of property, as noted earlier, is depersonalization and standardization in order to make the way smooth for coordination in general and transfers in particular, by rendering them less dependent on complex information. In the realm of property proper, there are reasons to think that the state has an advantage in supplying standardization of

${ }^{47} I d$.

${ }^{48}$ See, e.g., Oliver Williamson, Corporate Governance, 93 YALE L.J. 1197, 1210 (1984).

${ }^{49}$ See, e.g., Eugene F. Fama \& Michael C. Jensen, Agency Problems and Residual Claims, 26 J.L. \& Econ. 327 (1983).

50 See, e.g., Margaret M. Blair \& Lynn A. Stout, A Team Production Theory of Corporate Law, 85 VA. L. REv. 248 (1999); Margaret M. Blair \& Lynn A. Stout, Corporate Accountability: Director Accountability and the Mediating Role of the Corporate Board, 79 WASH. U.L.Q. 403 (2001); but see, e.g., Mark E. Van Der Weide, Against Fiduciary Duties to Corporate Stakeholders, 21 DEL. J. CoRP. L. 27 (1996); JosEPH F. JoHNSTON, No Man CAN SERVE Two MASTERS: SHAREHOLDERS VERSUS STAKEHOLDERS IN THE GOVERNANCE OF CoMPANiES (1998); see also Jonathan R. Macey, Fiduciary Duties as Residual Claims: Obligations to Nonshareholder Constituencies From A Theory of the Firm Perspective, 84 CORNELL L. REv. 1266 (1999).

51 Robert Clark, Corporate LaW 20 (1986); but see Jonathan R. Macey, An Economic Analysis of the Various Rationales for Making Shareholders the Exclusive Beneficiaries of Corporate Fiduciary Duties, 21 STETSON L. REV. 23, 33 (1991) (arguing that "too many masters" argument is overstated because of complex share structures whose holders can have conflicting interests). 
property rights. ${ }^{52}$ The state is already in the business of enforcing property rights, and there are probably economies of scope in adding standardization to the lists of tasks of the enforcer. On the supply side of property rights, there may be economies of scale as well: defining the life estate and other in rem rights society-wide makes sense. (And more idiosyncratic rights can be achieved in personam, through contract.) Likewise, property rights and legal styles exhibit network effects, so it makes sense to have one standard set of property rights. ${ }^{53}$

Standards can operate on smaller scales but for similar reasons. Standardization is also a by-product of modularization. The point of defining interface conditions in technology or law is to allow the components to work together in predictable ways, such that one component can be substituted for another as long as the interface conditions - the standards - are respected. ${ }^{54}$

Thus, we might regard standard-setting organizations as a form of entity property where the standardization function is a specialized module. As with other forms of entity property and other types of separation, the main resulting issues are strategic behavior and its containment, as we will see.

\section{Standard Setting Organizations as Entity Property}

Standard-setting organizations (SSOs) involve another kind of separation, with attendant benefits of specialization and costs of strategic behavior. And, as we will see, these characteristic property problems can and should be expected to lead to characteristic property solutions.

Previous literature has noted the links between property and organizations, property and technology, and organizations and technology. ${ }^{55}$ Taken as a whole, this literature emphasizes how modularity allows for complexity by managing information flow, on each of these levels - property, organizations, and technology. Moreover, the various strands of this literature all reflect what could be termed a "mirror principle." For legally constructed levels like property and organizations to be effective, they should mirror the pattern of interactions in the world (as well as shape them). In property theory, the problem of scale is a prominent example: the set of boundaries should "contain" interactions involving complementary attributes

\footnotetext{
52 Merrill \& Smith, supra note 14, at 51.

53 Yun-chien Chang \& Henry E. Smith, An Economic Analysis of Civil versus Common Law Property, 88 NotRe DAME L. REV. 1 (2012).

${ }^{54}$ See, e.g., BALDWIN \& CLARK, supra note 3 , at 12-13, 123-46.

${ }^{55}$ See the sources cited in note 3 supra. See also, e.g., Melissa A. Schilling, Toward a General Modular Systems Theory and Its Application to Interfirm Product Modularity, 25 ACAD. MGT. Rev. (2000).
} 
and not leave parts of important clusters of interactions on either side of the divide. ${ }^{56}$ What makes the organization of one level in terms of another a "property" problem is the impossibility of accomplishing this by contract alone.

One function of property and of the property element in organizations is to standardize the components of interactions between agents in order to make smoother the interactions between modules. The most formalized and flexible version of such interactions occurs under contracts. For this reason, standardization to facilitate transfer is particularly salient. ${ }^{57}$ Consider contract rights that are to be assigned or sold. They are depersonalized so that, in order to know what he is getting, the transferee need not evaluate the personal characteristics of the transferor and of earlier transactors. Negotiability is an extreme example of this depersonalization, under which a holder in due course takes free of the defenses of prior holders of an instrument. 58 This makes the instrument easier to sell, because it requires less evaluation to reduce risk.

In this Part, I show how the separation of the standardization function is not only possible but desirable, as long as the problem of strategic behavior can be sufficiently countained. I will show that the information cost theory of property (and intellectual property) helps explain the contours of SSOs. Separation of standard setting is a form of entity property that, like other forms of entity property, helps facilitate specialization while managing complexity. But separation and specialization lead not only to information specialization but also to externalities: modularization is vulnerable to misuse if actors behave opportunistically where the interface conditions do not fully capture relations of economic significance. SSOs rely on the full range of property solutions to the problem of strategic behavior.

\section{A. SSOs and Separation}

Can the standardization function be separated? Yes: this is what SSOs do. Here the standardization is somewhere in between contract and property, between in personam and in rem. In an SSO, the standard is not being set by the government alone, as in the case of property, but rather by group contracting. The standard is meant to bind the group and sometimes to attract others. The SSO functions as its

\footnotetext{
${ }^{56}$ See, e.g., Lee Anne Fennell, Commons, Anticommons, Semicommons, in Research HANDBook on the ECONOMICS OF PROPERTY LAW, supra note 15, at 35, 48; Dean Lueck, The Economic Nature of Wildlife Law, 18 J. LEGAL STUD. 291, 300-03 (1989); Smith, supra note 5, at S454,

57 Of two basic types of standards, one promotes economies of scale and the other lowers transaction costs. See Charles P. Kindleberger, Standards as Public, Collective and Private Goods, 36 KyKLOs 377 (1983); see also Richard N. Langlois \& Deborah Savage, Standards, Modularity, and Innovation: The Case of Medical Practice, in Path Dependence and Path Creation 149, 150-51 (Raghu Garud \& Peter Karnøe, eds., 2001).

${ }^{58}$ See supra note 44 and accompanying text.
} 
own institution, ${ }^{59}$ with the purpose of furthering the interface function of property. SSOs are thus a form of entity property, because the control of the standard and the employment and enjoyment of assets and activities related to the standard are separated and placed in different hands. Those deciding on the standard are a smaller group of specialists (as where a subset of industry participants create a standard that catches on in an entire industry), or industry participants with a separately defined persona. As with other kinds of separation, this opens up the possibility of both greater specialization and strategic behavior. Further, because the separate assets of the participants are not accessible to the SSO, which may even be ignorant of them, firms that participate in SSOs act in a different capacity than as competitors. In other words, the SSO itself is semi-modularized.

In SSOs, the standardization function is separated, but only partially, from the assets controlled by the industry participants - the individual firm-modules. Recall that in Spulber's separation criterion, an organization counts as a firm if the decisions about the agenda of the organization can be separated from the interests of the individual owners. ${ }^{60}$ On this criterion, an SSO is not a firm, and that should not surprise us. SSOs are thinner than even cooperatives, and they are potentially subject to capture by interested participants - an issue to which I return shortly. Nevertheless, a certain function, standardization, is partially modularized. The interface between this function and the industry, including the firms participating in the SSO, does not block as many interactions as the boundary of a firm or an individual asset would. But the weak interface does, like these more stringent interfaces in firms and property generally, allow for specialization: the SSO makes the standards, and the individual firms produce and engage in other business, without having to mix up these functions. And the standard itself allows the other activity to occur in a more modularized fashion. That is the purpose of standards. The problem is that specialized standard setting across a weak interface invites strategic behavior by actors who treat the standard setting and their own individual activities as not being separate. In other words, a firm may let its individual interests influence its role in the standard setting organization, to the overall detriment of the group and society.

So hiving off the standardization of interactions can, like other forms of separation, lead to strategic behavior. Consider the simplest forms of property again, say the fee simple in Blackacre. When we say that there are externalities of the owner's use of Blackacre, we mean that an activity that is protected by ownership has an impact on others that does is not brought home to the owner through the value of the Blackacre directly or indirectly through market prices, fines, and the like. Large parcels would not involve such externalities, but would not allow for specialization either. Entity property leads to the same benefits of

\footnotetext{
${ }^{59}$ See Langlois \& Savage, supra note 57 , at 150-52.

${ }^{60}$ Spulber, supra note 35 , at 302-03.
} 
specialization and dangers of strategic behavior. When assets are defined for liability or roles are separated, actors will care about the piece of the system to which their fortunes are tied and not to those of others. Thus, in a corporation, holders of equity will favor more risk than will holders of debt (and more than a unitary owner would), and holders of debt will favor too little if is given the choice. And the separation of ownership and control in certain business organizations like the corporation is famous for agency costs, which are simply the externalities that follow from modularization in the service of informational and functional specialization.

Similar benefits of specialization and strategic behavior arise in SSOs. The participants in standard setting can be expected to favor standards that advantage themselves individually even if this is overall wealth decreasing. In a sense, an SSO is a semicommons in that the standard setting is a common-property-like arena but one which overlaps and interacts with the individual property of the participants. ${ }^{61}$

The most discussed problem with SSOs centers on the role of participants' interests in their own intellectual property. A participant might seek to get a standard adopted and only later reveal that it is covered by a patent held by that participant. If at this point it would be difficult to change the standard, the participant can wield hold up power. There is a lively debate about the significance of this problem and how to solve it. ${ }^{62}$

To some extent, SSOs should be able to solve the problem, through their own rules. By mandating disclosure and licensing, for example by requiring ex ante fair, reasonable, and nondiscriminatory (FRAND) licensing, the other participants in an SSO can protect themselves from being sandbagged by a patent. As with scattering in the open fields, we also might expect to see SSOs employ devices to obscure how a standard will impact individuals. One method is to devise a standard early, if possible before the participants' interests have a chance to diverge.

\footnotetext{
61 See supra notes 22-26, and accompanying text.

62 See the sources cited in note 1 supra. See also, e.g., Kobayashi \& Wright, supra note 70; George S. Cary et al., The Case for Antitrust Law to Police the Patent Holdup Problem in Standard Setting, 77 AnTitruST L.J. 913 (2011); Bruce H. Kobayashi \& Joshua D. Wright, The Limits of Antitrust and Patent Holdup: A Reply to Cary et al., 78 AnTITRUST L.J. 505 (2012). This is part of a larger literature on patent hold up. See, e.g., Vincenzo Denicolò et al., Revisiting Injunctive Relief: Interpreting eBay in High-Tech Industries with Non-Practicing Patent Holders, 4 J. COMPETITION L. \& ECON. 571, 590-91 (2008); Einer Elhauge, Do Patent Holdup and Royalty Stacking Lead to Systematically Excessive Royalties?, 4 J. Competition L. \& Econ. 535, 557 (2008); Damien Geradin \& Miguel Rato, Can StandardSetting Lead to Exploitative Abuse? A Dissonant View on Patent-Hold Up, Royalty Stacking and the Meaning of FRAND, 3 EuR. Competition J. 101 (2007); John M. Golden, Principles for Patent Remedies, 88 TEXAS L. REV. 505, 566 (2010); Mark A. Lemley \& Carl Shapiro, Patent Holdup and Royalty Stacking, 85 TEXAS L. REV. 1991 (2007); J. Gregory Sidak, Holdup, Royalty Stacking, and the Presumption of Injunctive Relief for Patent Infringement: A Reply to Lemley and Shapiro, 92 MinN. L. REV. 714 (2008).
} 
Another method of dealing with the potential for strategic behavior is to try to align incentives, though a promise to cross-license. ${ }^{63} \mathrm{~A}$ commitment to crosslicense reduces the distance between the overall benefit of the standard and the private benefits from any patent that might cover the standard. This method does not align incentives for decision making perfectly if the owner of the patent stands to earn a fee from licensing, either to the other participants in the SSO or to third parties. (Some such requirements in SSOs allow members to license such patents for a fee, and others require free licenses.)

Such contractual solutions provide only partial or no protection to parties outside the SSO who may adopt the standard.64 For third parties, a more "in rem" solution is required, if there is to be one at all. This could be fully in rem in the sense of property, or it could be quasi in rem, in that it would hold only for a defined noncontractual group. The most well-known such intermediate solution is the tort of misappropriation in which the duty not to misappropriate holds for those in direct competition..$^{65}$

Also moving away from the classic contractual default paradigm would be mandatory rules imposed on SSOs. Because SSOs can solve many of their problems ex ante and they are typically sophisticated parties, SSOs are not good candidates for mandatory rules. ${ }^{66}$ However, to the extent that true surprise is involved, there is some scope for mandatory rules. Moreover, sophisticated parties might not opt out of general standards like good faith if they can anticipate in general outline the types of problems that opportunism based on the letter of a contract would give rise to. I return in the next Part to the question of where intervention in the style of equity should fall on the spectrum from default to mandatory rules.

Many commentators have argued that the potential for patent holdup in SSOs is a reason to weaken intellectual property rights (and patents in particular). They see the problem of unfair surprise as being of a piece with the type of bad notice and holdup power wielded by trolls. ${ }^{67}$ The most expansive of such IP-skeptical accounts

\footnotetext{
${ }^{63}$ See Lemley, supra note 1.

64 In his survey, Lemley also found that many of the understanding were unwritten and lawyers for participating firms usually were not heavily involved in the standard setting process, leaving it mostly to engineers. Lemley, supra note 1, at 1907.

65 Int'l News Serv. v. Assoc. Press, 248 U.S. 215 (1918). Shyamkirishna Balganesh, Quasi-Property: Like, But Not Quite Property, 160 U. PA. L. Rev. 1889 (2012); Henry E. Smith, Equitable Intellectual Property: What's Wrong with Misappropriation? (forthcoming in Shyamkirishna Balganesh ed., Intellectual Property and the Common Law, Cambridge University Press).

${ }^{66}$ See Lemley, supra note 1, at 1948-57.

${ }^{67}$ See, e.g, James Bessen \& Michael J. Meurer, Patent Failure: How Judges, Bureaucrats, ANd Lawyers PuT INNOVATORS AT RisK 10 (2008) (discussing how "the implementation of patent notice suffers important deficiencies").
} 
would treat every non-practicing entity (NPE) as a troll whose patent rights should be denied or subjected to compulsory licensing. ${ }^{68}$

Such broad-brush solutions should give us pause. For one thing, SSOs present their own set of dangers, which compulsory licensing could exacerbate. They can be used as a cover for cartelization. And unless one thinks the patent system is close to being an unmitigated bad, then giving SSOs strong powers to weaken patents carries with it the danger of undoing the benefits of the patent system.

Furthermore, others have argued that patent law itself has the potential for solving the hold up problem in SSOs. Patent law solutions vary in how much change in patent law is required to solve the problem. Some see the problem of holdup in SSOs and more generally as a reason to move away from injunctions and towards compulsory licensing. ${ }^{69}$ Others see a more robust notion of patent estoppel as a solution to the holdup problem. ${ }^{70}$

I will argue in the following that property law provides even more systematic tools for solving the problems with patent holdup. The suitability of property stems partly from the fact that it solves problems with a similar structure for tangible assets. More fundamentally, the similarity of the benefits of specialization and the pitfalls of strategic behavior arise in tangible property as well.

\section{B. Intellectual Property as Property}

When commentators consider whether intellectual property is property or not, they usually have one of several subsidiary questions in mind. These questions related to the purposes of property. I will argue that these typical views on the relationship of property and intellectual property obscure the role that property does and should play in SSOs.

\footnotetext{
68 See, e.g., Michele Boldrin \& DAVID K. LEVIne, AGAinst InTEllECTUAL Monopoly (2008) (arguing that patent and copyright should be done away with); Jaideep Venkatesan, Compulsory Licensing of Nonpracticing Patentees after eBay v. MercExchange, 14 VA. J.L. \& TECH. 26, 31 (2009) (describing courts as having substantially "decided, though not always expressly, that a nonpracticing patentee is entitled only to [a] royalty").

${ }^{69}$ See, e.g., Stewart E. Sterk, Property Rules, Liability Rules, and Uncertainty about Property Rights, 106 MicH. L. REV. 1285, 1334 (2008).

70 Bruce H. Kobayashi \& Joshua D. Wright, Federalism, Substantive Preemption, and Limits on Antitrust: An Application to Patent Holdup, 5 J. Competition L. \& Econ. 469 (2009).
} 
According to one well-known economic account of property, the purpose of property rights is to internalize externalities. ${ }^{71}$ In the case of tangible resources, the externality takes the form of the consumptive use of the resource (either the flow of renewable services or the stock). Multiple people cannot farm the same land or eat the same apple. Property rights are therefore sometimes said to solve an "allocation problem," because not everyone can enjoy the resource. Closely related is the idea that people will not invest in or conserve resources if they do not enjoy the fruits of their labor or other inputs. Thus, property rights solve an "appropriation" problem. But again, IP skeptics will point out that information as a nonrival resource can be used by multiple parties and so need not be allocated or appropriated. ${ }^{72}$

The case for intellectual property rights cannot rest on a direct application of the need for allocation or appropriation of information itself, so the case for intellectual property operates at a slight remove. Yes, information can be consumed by multiple people (it is nonrival), but without a reward it won't be produced in the first place. So there is a dynamic case for intellectual property, based on the fixed costs of producing the information. The rejoinder by the skeptic is that there might well be more efficient - less costly - ways to reward invention than handing out "monopoly" property rights. ${ }^{73}$

Although this paper is not the place to canvass theories of intellectual property or patents in particular, the major strains of justification for intellectual property that move beyond the reward theory relate to commercialization and the promotion of transactions. ${ }^{74}$ As in property law, the ability to appropriate the

\footnotetext{
${ }^{71}$ See Harold Demsetz, Toward a Theory of Property Rights, 57 Am. ECon. Rev. 347 (1967) (Papers \& Proc.).
}

72 See, e.g., Mark A. Lemley, Property, Intellectual Property, and Free Riding, 83 TeXAS L. Rev. 1031 (2005) (arguing for detaching intellectual property from property, reconceptualizing it as tort or regulation, and even relabeling it "IP" to obscure the connection); see also LAWRENCE LESSIG, THE FUTURE OF IDEAS: THE FATE OF THE COMMONS IN A CONNECTED WORLD 161 (2001) (contending that the process of enclosure, in which media and software companies propertize information, is stifling innovation in the new economy; Jesse Walker, How Intellectual Property Laws Stifle Popular Culture, REASON, Mar. 2000, at 46, available at http://www.reason.com/news/show/27635.html (arguing that IP is a government granted monopoly and should be disfavored).

${ }^{73}$ For example there is a large literature on direct rewards. See, e.g., Michael Abramowicz, Perfecting Patent Prizes, 56 Vand. L. Rev. 115, 123-24 (2003); Steven Shavell \& Tanguy van Ypersele, Rewards Versus Intellectual Property Rights, 44 J.L. \& EcoN. 525, 534-45 (2001).

${ }^{74}$ For statements of the commercialization theory, see, e.g., F. Scott Kieff, Property Rights and Property Rules for Commercializing Inventions, 85 MINN. L. REv. 697 (2001) (arguing that the commercialization function requires property rule protection for patents); Giles S. Rich, The Relation Between Patent Practices and the Anti-Monopoly Laws, 24 J. PAT. OFF. Soc'Y 159, 177-81 (1942) (arguing that promoting the commercialization of inventions is the most important function of patent law); see also Edmund W. Kitch, The Nature and Function of the Patent System, 20 J.L. \& Econ. 265, 276-77, 284

(1977) (discussing, inter alia, the role of patent prospect in giving "the patent owner ... an incentive to make investments to maximize the value of the patent," including investments in manufacture, distribution, and market development). 
return from a cluster of attributes can be packaged and transferred. ${ }^{75}$ As I will show, the modular theory of property points to a strong role for commercialization concerns to shape intellectual property.

To return to regular property, the function of exclusion strategies is to provide semi-opaque modules that allow for specialization. Owners can develop information about their assets and coordinate uses without having to answer to or provide their worth to outsiders (including judges). ${ }^{76}$ As noted earlier, owners can contract in a smoother way if ownership is depersonalized so that a successor owner can step into the current owner's shoes. Crucially, an exclusion strategy operates indirectly. ${ }^{77}$ It uses rough proxies like the crossing of a boundary of a parcel or the touching of a chattel to signal violations, often with little or no inquiry into harm or evaluation of uses. By contrast, governance strategies, like those in nuisance, do require harm and some balancing of competing uses. So a big difference between exclusion and governance is in their degree of directness: while governance strategies typically make direct reference to uses and focus in on smaller classes of uses, exclusion strategies do protect interests in use, but only indirectly. By having a possessory right protected by the law of trespass a landowner can pursue many uses - growing crops, parking cars, living in residence - without fear of interference or the need to justify the value of those uses. Nevertheless the terms of the exclusion strategy do not make reference to those uses - they are internal to the modular that is the package of property rights.

The lack of reference to uses in exclusion strategies is important to the role of exclusion strategies in intellectual property. ${ }^{78}$ Intellectual property rights allow for appropriation of the returns from rival assets. ${ }^{79}$ Think labor, lab space, advertising inputs, etc. Intellectual property rights also package inventions for transfer such that the opportunity to employ rival assets in a particular way and be transferred to another party, in whole or in part. ${ }^{80}$ The trigger for violation of the

\footnotetext{
75 On the role of patents in promoting transactions, see Paul J. Heald, A Transaction Costs Theory of Patent Law, 66 Онго Sт. L.J. 473 (2005) (asset partitioning); Robert P. Merges, A Transactional View of Property Rights, 20 BERKELEY TECH. L.J. 1477 (2005) (precontractual liability and enforcement flexibility from IP support exchange); Oskar Liivak, Establishing an Island of Patent Sanity (draft Cornell Law School) (patent law providing support for voluntary exchange of inventions).

${ }^{76}$ Henry E. Smith, Property and Property Rules, 79 N.Y.U. L. Rev. 1719, 1022-43 (2004).

77 See Henry E. Smith, Mind the Gap: The Indirect Relation Between Ends and Means in American Property Law, 94 CoRnELL L. REv. 959 (2009); Smith, supra note 5.

${ }^{78}$ Henry E. Smith, Institutions and Indirectness in Intellectual Property, 157 U. PA. L. REv. 2083 (2009).

${ }^{79}$ See, e.g., Kitch, supra note 74, at 1745 n.4; Oskar Liivak, Maturing Patent Theory, 86 TuL. L. Rev. 1, 25 (2012); Henry E. Smith, Intellectual Property as Property: Delineating Entitlements in Information, 116 YALE L.J. 1742, 1745-46, 1765-66, 1780-82 (2007).

${ }^{80}$ See the sources cited in note 75 supra.
} 
rights that protect this nexus of opportunities to commercialize is "practicing the invention" and in particular the invention as described in the claims of the patent.

The modular theory of property and intellectual property helps make sense of why property is necessary in the first place. Without it commercialization would involve the need to separately trace the contributions of rival inputs into products. Moreover signaling these inputs and transferring them in useful packages would be more difficult. So intellectual property rights do serve as a beacon, ${ }^{81}$ but they are not pure notice giving devices. They do allocate - not information, but the opportunity to develop a cluster of information related rival resources. Property rights do allow for coordination, but not just any coordination, like driving on one side of the road. The coordination facilitated by property rights involves appropriation of the returns form rival assets - the inputs to commercialization.

Even if intellectual property serves multiple purposes, commercialization may be the operative theory on the margin in patent law, helping to explain the shape it takes. SSOs respond to need for better interoperability of technology and rights. Standard-setting organizations are a missing piece of the puzzle: they align intellectual property rights, organizations, and technology, mainly in the realm of interaction, and especially transfer. SSOs provide the numerus clausus-like aspect of property, separable from the appropriability. This is a form of breaking up property (along a different fault line), and like other separations it promotes specialization.

\section{Patent Hold-up in SSOs as a Property Problem}

In this Part, I argue that traditional equity, operating both through remedies and substantively, is a potential solution to the holdup problem. Importantly, equity here would be serving what I have argued is one of its most general functions: counteracting opportunism. ${ }^{82}$ Equity serves this role in property generally, and thus property law - here including its equitable safety valve - is part of the solution to the holdup problem.

As with regular property, the exclusion-governance architecture supports specialization, leads to problems of strategic behavior, but also attempts to solve these problems. Equity as a safety valve is an important anti-opportunism device that applies throughout private law. ${ }^{83}$ As I have defined it elsewhere for these purposes, opportunism is "behavior that is undesirable but that cannot be cost-

\footnotetext{
81 F. Scott Kieff, Coordination, Property, and Intellectual Property: An Unconventional Approach to Anticompetitive Effects and Downstream Access, 56 EmoRY L.J. 327, 333-34, 346-47, 350-54 (2006).

${ }^{82}$ Henry E. Smith, An Economic Analysis of Law versus Equity (draft).

${ }^{83}$ For a model of the safety valve and an application to contracts and other areas, see Kenneth Ayotte, Ezra Friedman \& Henry E. Smith, A Safety Valve Model of Equity as Anti-Opportunism (draft).
} 
effectively captured - defined, detected, and deterred - by explicit ex ante rulemaking. Opportunism is residual behavior that would be contracted away if ex ante transaction costs were lower. "84 As a safety valve aimed at opportunism, equity is much better tailored to deceptive behavior, and indeed the focus traditionally in equity was "near fraud." 85 This is behavior that either is probably fraud but hard to prove, or behavior that is highly likely to involve fraud in a context that in light of the danger is not worthwhile to allow.

As in private law generally, equity serves as a safety valve aimed at counteracting opportunism. Equity is a decision-making mode associated roughly with historical equity, the law of the former courts of chancery. This decisionmaking mode is characterized by more morally based decision making, greater discretion, vagueness ex ante and specificity ex post. Equity does not declare property rights but only acts directly against the individual person (in personam). The prototypical application of equity is Riggs v. Palmer, 86 in which grandson Elmer murdered his grandfather, because Elmer feared the grandfather was going to change his will out of displeasure with him. When Elmer tried to take under the will or, alternatively, as an heir at law, which would technically follow, the court applied the principle (sometimes called a maxim) that one cannot profit form one's own wrong and disallowed this result. Equity uses a number of these maxims to guide the chancellor's discretion. ${ }^{87}$ It also affords equitable defenses of laches, unclean

\footnotetext{
${ }^{84}$ Smith, supra note 82 , at 10. in Exchange, 69 Cal. L. Rev. 1587, 1639 (1981). 2009).

87 The number varies, but here is a typical list.

1. Equity follows the law.

2. Equity will not suffer a wrong to be without a remedy.

3. Equity acts in personam, not in rem.

4. Equity is equality.

5. Equity regards as done that which ought to be done.

6. Equity regards substance rather than form.

7. She who seeks equity must do equity.

8. He who comes into equity must come with clean hands.

9. Equity aids the vigilant and diligent.
}

${ }^{85}$ Richard A. Epstein, Unconscionability: A Critical Reappraisal, 18 J. L. \& Econ. 293, 293, 293-301 (1975). On the nineteenth century view that unconscionability referred to fraud that could not readily be proved, see, e.g., Seymour v. Delancey, 3 Cow. 445, 521-22, 15 Am.Dec. 270 (N.Y. Sup. 1824) ("Inadequacy of price, unless it amount to conclusive evidence of fraud, is not itself a sufficient ground for refusing a specific performance of an agreement") (citing cases); James Gordley, Equality

8622 N.E. 188, 190 (N.Y. 1889) (employing principle that "[n]o one shall be permitted to profit by his own fraud, or to take advantage of his own wrong, or to found any claim upon his own iniquity, or to acquire property by his own crime" to justify enjoining administrator of estate from allowing any benefit to grandson who murdered testator); RESTATEMENT (THIRD) OF RESTITUTION AND UNJUST ENRICHMENT § 45(2) (2011) ("A slayer's acquisition, enlargement, or accelerated possession of an interest in property as a result of the victim's death constitutes unjust enrichment that the slayer will not be allowed to retain."). These days "anti-slayer" statutes typically cover many of these situations. See Jesse DukEminier, Robert H. SitKoff \& James Lindgren, Wills, TruSTS, AND Estates 149-51 (8th ed. 
hands, and estoppel (more on the last two in a moment), and as we will see employs a characteristic set of remedies including most famously the injunction.

Although it falls outside the scope of this paper, it is worth mentioning the tight historical and functional connection between equity and entity property. Most prominently, corporate law, the most well known form of entity property, gets its fiduciary duties from equity. Not coincidentally, the fiduciary function is aimed squarely at opportunistic behavior, the danger of which is at its height when a fiduciary acts on behalf of a principal. Corporate law evolved out of the trust, perhaps equity's most famous contribution Anglo-American legal systems (and now beyond). As noted earlier, the trust itself is a form of entity property (involving asset partition in particular). Again it was the grave danger of opportunistic behavior that got the chancellors involved in policing trustee behavior to begin with. Finally, it is also remarkable how historically equity has provided many of the other devices to police strategic behavior stemming from other separations in property discussed earlier. Take the divisions that form the basis of the estates in land and future interests, as well as the division into the leasehold and the package of rights retained by a landlord. In both cases, the law of waste applies to police the behavior of the one with control, in this case the holder of the possessory interest in order to prevent that person from acting opportunistically toward the holder of the reversion (or other interest not yet in possession).

As argued above, SSOs promote modularity for specialization, in this case of the standardizing function. Because the control and benefits of standardization are not perfectly matched, strategic behavior becomes possible. The specialization of information makes monitoring for strategic behavior more difficult. If individual firms hold intellectual property and are specializing in developing it, the decisions they make with respect to the industry standard-making process are hard to evaluate in light of the firm's interest. Modularization is supposed to leave such decisions in local and hands and not look over local actors' shoulders and secondguess their decisions, but this makes motoring more difficult. The point is information hiding, but information hiding not surprisingly leads to "hidden action" and asymmetric information problems. One can think of an SSO as a semicommons in which private intellectual property and the common property - the standard interact in nontrivial ways. Actions with respect to either regime can affect the assets in the other regime in hard-to-monitor ways.

Also as pointed out earlier, some of the contracting within SSOs can help deal with the problem of strategic behavior. Some decisions can be taken before one knows whether one will be licensor or licensee. Overall, governance regimes are

Roger Young \& Stephen Spitz, SUEM-Spitz's Ultimate Equitable Maxim: In Equity, Good Guys Should Win and Bad Guys Should Lose, 55 S.C. L. REv. 175, 177 (2003). For a discussion of how these maxims reflect a decision-making mode appropriate to a safety valve against opportunism, see Smith, supra note 82 . 
needed for resulting strategic behavior from mismatches between decisions and residual claims (agency costs, semicommons etc.).

Returning to equity as a device for solving these problems in a more ex post manner, this decision-making mode provides a ready-made off-the-rack governance regime. Interestingly, at least five aspects of equity offer potential solutions to the problem of patent holdup in general, and holdup in the context of SSOs in particular. They are: the standards for injunctions, the doctrine of estoppel, the defense of clean hands, legally protected custom, and unjust enrichment.

1. Injunctions. The literature on the dangers of injunctions in the hands of patent trolls and other holdup artists is vast. Indeed, the problem of patent trolls is what motivated the U.S. Supreme Court to set forth its supposedly traditional four-part test for injunctions in eBay Inc. v. MercExchange, L.L.C. 88

As Mark Gergen, John Golden, and I have argued elsewhere, the four-part test of eBay is a mistake in the making. ${ }^{89}$ To begin with, the supposedly "wellestablished" four-factor test is anything but, and is actually based on the test for preliminary relief (with a doubling up of the first factor). Under the four-factor test, the movant must show:

(1) that it has suffered an irreparable injury; (2) that remedies available at law, such as monetary damages, are inadequate to compensate for that injury; (3) that, considering the balance of hardships between the plaintiff and defendant, a remedy in equity is warranted; and (4) that the public interest would not be disserved by a permanent injunction. ${ }^{90}$

The Court touted this test as calling for exercise of judicial discretion consistently "with traditional principles of equity," 91 but as Gergen, Golden, and I show, this is anything but true, both in terms of the substance of the test and its likely function. The origins in the standard for preliminary injunctions should be suspect: at such an early stage the decision maker has not found a violation and must weigh hardship to both sides more equally for that reason.

Traditionally, the standard for injunctions did partake of equitable traditions, but these were based on presumptions and rules of thumb sounding in good faith and disproportionate hardship - both of which serve to counteract opportunism.

\footnotetext{
88547 U.S. 388, 391 (2006).

${ }^{89}$ Mark P. Gergen, John M. Golden \& Henry E. Smith, The Supreme Court's Accidental Revolution? The Test for Permanent Injunctions, 112 CoLUM. L. REV. 203 (2012).

90547 U.S. at 391.

91 Id.
} 
The $e$ Bay test omits all reference to good faith, but it was almost axiomatic in equity that denying an injunction to someone whose rights were violated would be inappropriate where the violator deliberately violated. The opportunism in that could hardly be clearer: the danger was that violators would game the system and cherry pick undervalued assets, especially ones where damages were hard to prove. (An as yet to be licensed patent would be a prime example.)

Equally interestingly, the "balance of the hardships" factor masks a lot of traditional, and highly functional, wisdom. As mentioned earlier, the traditional standard did not ask, as some modern commentators and courts would have it, ${ }^{92}$ whether the injunction would harm the nonmoving party more than it would help the movant. Instead, disproportionate hardship asked whether someone who would otherwise be entitled to an injunction for a rights violation should not get it because the benefit from the injunction would be far outweighed - out of all proportion - to the harm it would inflict on the innocent defendant. ${ }^{93}$ This is consistent with a targeted intervention against opportunists, because the disproportionate hardship can be regarded as a rough proxy for situations that carry a large danger of opportunism. ${ }^{94}$ As is often recognized, the structure here in patent law is little different from that in building encroachments, but that points neither to a flat rule for injunctions nor to one of damages all the time. Instead, the potential opportunism may be dealt with best by allowing for the robust injunctive remedy to presumptively protect patentees in general, especially against those in bad faith and by allowing a damages remedy when the type of situation is one in which the dangers of opportunism by the right holder exceeds the danger from the (innocent) encroacher. Interestingly, this traditional approach coincides with a strain of modern theorizing about intellectual property. 95

\footnotetext{
92 See, e.g., eBay, Inc. v. MercExchange, L.L.C., 2006 WL 1785363 (Appellate Brief) (U.S. Jun. 26, 2006) Brief Amici Curiae of 52 Intellectual Property Professors in Support of Petitioners (NO. 05$130)$, at 9.

93 See, e.g., Gergen et al., supra note 89, at 226-30; Douglas Laycock, The Neglected Defense of Undue Hardship (and the Doctrinal Train Wreck in Boomer v. Atlantic Cement), 4 J. ToRT L., no. 3, 2012, at 1, 4-5; Smith, supra note 82; see also HENRY L. MCCLINTOCK, HANDBOOK OF THE PRINCIPLES OF EQUITY 51 (2d ed. 1948) (observing that, when "the award of specific relief would inflict a hardship on the defendant which is out of all proportion to the injury its refusal would cause to plaintiff[,] ... the great weight of authority" holds "equity still has discretion in adjusting the relief to be rewarded"); Lee Anne Fennell, Efficient Trespass: The Case for "Bad Faith" Adverse Possession, 100 Nw. U. L. Rev. 1037, 1042 n.21 (2006) ("Although the specifics vary from jurisdiction to jurisdiction, and exceptions can be found, most modern American courts will deny injunctive relief in good faith encroachment situations where the injunction would impose a disproportionately heavy burden on the encroacher.").

${ }^{94}$ Henry E. Smith, Rose's Human Nature of Property, 19 WM. \& MARY BiLl RTs. J. 1047, 1053-54 (2011); Smith, supra note 82, at 34-36.

${ }_{95}$ Herbert F. Schwartz, Injunctive Relief in Patent Infringement Suits, 122 U. PA. L. REv. 1025, 1045-46 (1964) (suggesting a "grossly disproportionate hardship" standard); Smith, supra note 78, at 212533; Vincenzo Denicolò et al., Revisiting Injunctive Relief: Interpreting eBay in High-Tech Industries with
} 
The concurrences in eBay itself show how this unanimous opinion still masks a lot of disagreement, and the lower courts have taken up an invitation to deny injunctions to non-practicing entities. ${ }^{96}$ And unfortunately the $e$ Bay "test" has spread to through the federal courts and outside of intellectual property. ${ }^{97}$

A more traditional approach to equity and its role in counteracting opportunism would solve the problem of surprise patent assertion in SSOs in a more tailored fashion than simply denying injunctions to NPEs or moving towards fullblown mandatory compulsory licensing. By tailoring the safety valve to situations of simultaneous good faith and disproportionate hardship, equity minimizes the chilling effect on desirable behavior. "Garden variety" actors can go about their business. ${ }^{98}$ Subject to the precision of the proxy, opportunism is targeted ex post in a fashion that would be impossible to achieve ex ante. When the opportunist patent holder in the SSO has superior knowledge (especially when even general ex ante contracting about licensing runs out), equity steps in to prevent hard-to-foresee unintended exploitation of the SSO for private gain. An SSO that innocently but very publicly adopted a standard covered by a patent by a non-member should be able to invoke this escape hatch from injunctions as well. As some have noted, sometimes we might put the burden on someone asserting a patent to notify potential infringers. ${ }^{99}$ This makes more sense the worse the notification function of patents is working. ${ }^{100}$ Here is not the place to solve the interrelationship of notice giving and patent remedies, but depending on how these background issues are (or are not) solved, equity has a role to play in combatting opportunism on both sides - patentee and potentially infringers reliant on a standard promulgated by an SSO. This

Non-Practicing Patent Holders, 4 J. Competition L. \& Econ. 571 (2008).] Interestingly, despite his endorsement of a rule for injunctions in patent cases, eBay, Inc. v. MercExchange, L.L.C., 2006 WL 639164 (Appellate Brief) (U.S. Mar. 10, 2006) Brief of Various Law \& Economics Professors as Amici Curiae in Support of Respondent (N0. 05-130) (Richard A. Epstein, F. Scott Kieff, \& R. Polk Wagner), relying in part on an analogy to building encroachments, at 16-17, in other work he has endorsed withholding injunctions in cases of disproportionate hardship. See Richard A. Epstein, A Clear View of The Cathedral: The Dominance of Property Rules, 106 YALE L.J. 2091, 2102 (1997) (arguing that "essentially the appropriate solution is to allow injunctive relief when the relative balance of convenience is anything close to equal, but to deny it (in its entirety if necessary) when the balance of convenience runs strongly in favor of the defendant. The usual presumption is that the exploitation risk is greater than the holdout risk. This presumption can be reversed by a showing of the dramatic difference in values...").

96 [cites]

97 Monsanto Co. v. Geertson Seed Farms, 130 S. Ct. 2743, 2759 (2010). [cites]

${ }^{98}$ Ayotte, Friedman \& Smith, supra note 83.

99 See, e.g., Herbert Hovenkamp, Notice and Patent Remedies, 88 TEX. L. REv. SEE ALSo 221, 224 (2011), www.texaslrev.com/sites/default/files/seealso/vol88/pdf/88TexasLRevSeeAlso221.pdf.

100 On notice problems, see Bessen \& Meurer supra note 67. 
application of the standard for injunctions shades off into estoppel, which we take up next.

2. Estoppel. Estoppel is a general equitable doctrine that has been applied in patent law, and to deception in the context of SSOs in particular. As some commentators have argued, its specific form in patent law provides a potential solution to he problem of holdup, making expansive use of antitrust law unnecessary. ${ }^{101}$ Heretofore, in cases like Broadcom ${ }^{102}$ and Rambus ${ }^{103}$ and in much of the commentary, the focus has been on antitrust in dealing with deceptive behavior in SSOs, with mixed results. By contrast, equity squarely targets "near fraud," and opportunism often if not always involves some element of deception. Indeed Oliver Williamson defines opportunism "self-interest seeking with guile."104

Especially where a participant in an SSO has led others to believe that a proposed standard would not be covered by a patent or that the patent would not be asserted (or would be licensed), estoppel can be used to prevent assertion of the patent by the holder (or force a license). Some opportunistic behavior in the context of patent assertion falls under estoppel. One advantage of using the general equitable estoppel is that it is not limited to behavior in the seeking of a patent, known as prosecution history estoppel, a doctrine that prevents patentees from claiming under the doctrine of equivalents subject matter that was relinquished during patent prosecution (a specific form of inequitable inconsistency). ${ }^{105}$

Estoppel as a general equitable doctrine is consistent with the theory of equity as an anti-opportunism safety valve. It prevents persons from creating a misleading expectation by words, conduct, and sometimes even silence, inducing reasonable reliance, and then withdrawing it or contradicting it later to the material harm of the other. ${ }^{106}$ Opportunistic inconsistency is not allowed to prejudice those who rely. Thus, it might apply even to non-members of an SSO if the deception is bad enough or sufficiently targeted at a third party. The law of estoppel features an extensive variety of rules of thumb to target its anti-opportunistic effect. ${ }^{107}$

\footnotetext{
101 See, e.g., Herbert J. Hovenkamp, Standards Ownership and Competition Policy, 48 B.C. L. REv. 87, 105-06 (2007); Kobayashi \& Wright, supra note 70, at 504-05.

102 Broadcom Corp. v. Qualcomm Inc., 501 F.3d 297 (3d Cir. 2007).

103 Rambus Inc. v. F.T.C., 522 F.3d 456 (D.C. Cir. 2008).

104 Oliver E. Williamson, The EConomic Institutions of CAPitalism 47 (1985). Williamson's definition of guile is probably more expansive than what we need to explain equity.

105 See, e.g., Wang Labs v. Mitsubishi Elecs., 103 F.3d 1571, 1578-79 (1997).

106 [cites]

107 [cites]
} 
3. Clean Hands. Closely related to the doctrine of estoppel is the defense of clean hands. ${ }^{108}$ "Unclean hands" is also a defense closely related to the maxim of not profiting from one's own wrong (here with the court's aid). ${ }^{109}$ Equity withholds its aid from someone who has behaved contrary to commercial morality in the transaction in question. (General unrelated bad behavior does not count, thus cabining the defense somewhat. ${ }^{110}$ ) Thus, if someone misleads others in in an SSO into adopting a standard that is secretly covered by that person's patents, the members of the SSO might be able to raise the defense of unclean hands to an enforcement action.

4. Custom. To cabin equity, one can look to custom as the source of a trigger for intervention against opportunists. Equity has historically played a role in the employment of custom by the law, either as a substantive standard or as evidence of good versus bad faith. 111 When the law (including equity) looks to custom it imposes its somewhat more formal template on it. Typically the law will formalize custom in the process of incorporating it (or recognizing it). ${ }^{112}$ As a result, custom is more than the judge's felt sense of morality.

108 See, e.g., Carmen v. Fox Film Corp., 269 F. 928 (2d Cir. 1920).

109 The Second Circuit recently captured this relationship well:

"Chutzpah" as a legal term of art is analytically similar to "unclean hands," though not necessarily coterminous with that concept as understood in Chancery. The "classic definition" of chutzpah has been described as "that quality enshrined in a man who, having killed his mother and father, throws himself on the mercy of the court because he is an orphan." Leo Rosten, The Joys of Yiddish 92 (1968). Courts in this Circuit have employed the "classic definition" and contemporary variations where a party's conduct is especially and brazenly faulty.

Motorola Credit Corp. v. Uzan, 561 F.3d 123, 128 n.5 (2d Cir. 2009) (Cabranes, J.) (citations omitted) (summarizing cases involving former state senator serving sentence for selling stolen bonds who sued purchasing bank for negligence in accepting the bond leading to his conviction, and case in which a person who was mauled by the 450 -pound Siberian tiger he was raising along with an alligator sued city and police attempting to rescue the animals for entering without a search warrant.)

110 Scattaretico v. Puglisi, 799 N.E.2d 1258, 1261-62 (Mass. App. Ct. 2003) ("A person is not to be deprived of civil justice merely because he has sinned in the past; his wrongdoing must have been related directly to the present situation to justify his being barred."); id at 1262 n.16 [Chief Baron Eyre who, according to Chafee, supra at 8, first uttered the maxim, "A man must come into a Court of Equity with clean hands," was well aware of the point: "it does not mean a general depravity; it must have an immediate and necessary relation to the equity sued for." Dering v. Earl of Winchelsea, 1 Cox Eq. 318, 319, 29 Eng. Rep. 1184, 1185 (Ex. 1787).]

111 See Robert G. Bone, Personal and Impersonal Litigative Forms: Reconciling the History of Adjudicative Representation, 70 B.U. L. REv. 213 (1990); Emily Kadens, The Myth of the Customary Law Merchant, 90 TEXAS L. REv. 1153, _ (2012) (evidence of good faith).

112 See Henry E. Smith, Community and Custom in Property, 10 Theoretical InquiRIES L. 6, 35-36 (2009). 
In the context of an SSO, there may be industry trade custom or customs surrounding the SSP that prescribe openness about patents - or not profiting from a patent covered by a standard. By its nature, solutions to the holdup problem involving custom are specific to an industry or an SSO. In the future, those setting up SSO could use awareness of the role of equity in enforcing custom (as well as unjust enrichment) to set up a custom that would allow opportunists to be dealt with through equity.

5. Unjust Enrichment. An underappreciated arena for equitable principles is the law of unjust enrichment. Stated in its most general form, one might think it would apply to a patent holder who sits quietly by, especially as a member of the SSO, and lets the organization adopt a standard covered by its patent. At this level of generality, unjust enrichment seems too vague and expansive. The law of restitution, which is based substantively on unjust enrichment (in whole of in part, depending on who one is to believe), traces back to earlier equity (constructive trusts) and law (quasi-contract), but the entire field has long been thought to partake generously of the equitable decision-making mode (even the parts on the law side). ${ }^{113}$ What makes the enrichment unjust? As with unclean hands and custom, it is preferable to be able to point to some widely accepted commercial morality. I leave it open as to whether this is so.

Less expansive versions of unjust enrichment ground the unjustness in a contractual undertaking if there are such. Andrew Kull, the Reporter for the recent Restatement (Third) of Restitution and Unjust Enrichment has long argued, ${ }^{114}$ and has now implemented in the Restatement, ${ }^{115}$ the position that unjust enrichment in the context of a bargain should use that bargain as a reference point, even if it is not enforceable as a contract. ${ }^{116}$

Because SSOs often do involve contracts, but ones that may or may not be enforceable, unjust enrichment provides a promising avenue to prevent

113 See Moses v. Macferlan, (1760) 97 Eng. Rep. 676, 681 (K.B.) (Mansfield, J.) ("In one word, the gist of this kind of action is, that the defendant, upon the circumstances of the case, is obliged by the ties of natural justice and equity to refund the money.").

${ }^{114}$ As Kull puts it:

Where a benefit is conferred pursuant to a valid contract, the presence or absence of unjust enrichment - the starting point of analysis in restitution - can only be determined by reference to the parties' bargain. Because a voluntary agreement fixes the baseline of enrichment as between the parties, the existence of a valid contract to govern a particular transaction normally establishes a boundary beyond which liability in restitution cannot extend.

Andrew Kull, Rationalizing Restitution, 83 CAL. L. Rev. 1191, 1200 (1995).

115 [cite]

116 [cites] 
opportunism. The profits derived from the deception involved in going against an SSO's widespread understanding, whether this is a contract, a custom, or something comparably concrete, could be subject to a claim by the other members of the SSO sounding in unjust enrichment.

\section{Conclusion}

Intellectual property and property can get along equitably. Intellectual property is not the same as property in all respects, but it does involve the same exclusion-governance architecture. Particularly where property rights involve separation along various dimensions, these institutions promote specialization at the cost of inviting strategic behavior. These benefits and costs of separation are rampant in "entity property," which involves separation of various kinds of control from various kinds of enjoyment. SSOs can be regarded as a form of entity property or at least organization where the standardization function of property is hived off and controlled separately from the activities that benefit from the standards. In property - "regular," intellectual, and entity - a range of governance regimes, some off the rack and some contractual can deal partially with strategic behavior stemming from separation. But one tool of general applicability is the ex post, in personam device of equity, which uses rules of thumb couched in moral terms to counteract opportunism. Through its specific aspects - the standards for injunctions, estoppel, clean hands, custom, and even unjust enrichment - equity helps solve the problem of opportunism to which separation of the function of standardization gives rise. In this respect, traditional property is not just part of the problem but also provides solutions to the controversies over intellectual property in SSOs. 